\title{
LEGAL ASPECTS IN COASTAL PROTECTION ENGINEERING
}

\author{
W. Turner Wallis \\ Engineer, Trustees of the Internal \\ Improvement Fund, Tallahassee, Florida
}

\section{A LEGAL BASIS FOR COASTAL PROTECTION}

In modern systems of democratic government the basic recourse for the necessary authority and power for solving problems is in the enactment of laws. These laws may vary extensively in character and content from the comprehensive acts of a congressional body to the simplest ordinances of a town council, but each provides a means acceptable to the people for implementing a desired program. Such is the case in the preservation of beaches and the protection of coastlines.

It is safe to assert that without the benefit of some legal basis, nothing would be undertaken beyond individual attempts to control tne forces, natural and cultural, which threaten the shoreline. Coastal laws are necessary. They acknowledge the problen and the need to combat it. Yet, with continued efforts to refine the law and detail the most minute principles of implementation, it loses its value as the servant of the people and becomes tne master - a coastal protection program no longer flexes to a contemporary situation, but is governed by the limitations of the law.

A sound coastal protection program, then, should be based on a law more general and adaptable than specific and rigid. It should recognize the preservation of shores and beacies as a public responsibility, and should provide autho. ity and means for the discharge of this responsibility. Sucl a simple statement of the issue is misleading, however. If the legal prerequisites are so elementary, there must be som reason why every political entity with a coastal problem doe not have a basic law conducive to a successful protective an remedial program. The explanation for this is not in the law itself.

Florida is a prime 1llustration. Since 1931 - for more than a quarter century - this state has had in its statutes a provision intended to authorize, if not direct, a program of almost unlimited scope for the administration of state lands by the Trustees of the Internal Improvement Fund a board comprised by five cabinet members acting ex officio. Section 253.03, Florida statutes, reads in part: 


\section{LEGAL ASPECTS IN COASTAL PROTECTION ENGINEERING}

The Trustees of the Internal Improvement Fund of the state are vested and charged witil the administration, management, control, supervision, conservation and protection of all lands and products on, under, or growins out of, or comnected with, lands owned by, or which may hereafter inure to, the state, not vested in some other state agency. Such lands shall be deemed to be.... all lands owned by the state ky right of its sovereignty . . . all tidal lands . . . all lands covered by shallow waters of the ocean, gulf, or bays or lagoons thereof, and all lands owned by the state covered by fresh water... . all lands which have accrued, or which may hereafter accrue, to the state from any source whatsoever, unless or until vested in some other state agency.

General though it may be, sufficient authority is contained in this section to have enabled long ago the initiation of coastal protection work. The aforementioned Trustees, who have the power to approve disbursements from the Internal Improvement Fund for a "Iiberal system of' internal improvements", might lesally have instituted a program of coastal improvements as well. In'its permissive aspects, this law is entirely adequate. Yet, today, Florida suffers coastal problems as critical as any in the world, and lags far behind in application of modern coastal engineering techniques.

Cursory analysis is sufticient to note that coastal problems in Florida have not gone unattended through absence of legal authority to cope with the situation. Progress within the state in recent years, stimulated largely by the efforts of the Coastal Engineering Laboratory at the University of Florida, provides encouraging evidence that such activities can be conducted in harmony with, if not as a product oI', the existing law. To be sure, a law with more specific references to beach erosion and coastal protection might have been utilized more extensively; but basically, the relative inactivity in this fleld in Florida has been a consequence of widespread ignorance and apathy on the part of the people. Despite acute natural problems and Florida's economic interest in shores and beaches of the state, a strong protective program has not developed primarily because the people have been unaware of the situation and have not been inclined to support the much needed program. This problem is not confined to Florida.

To correct this situation, no amount of legal reform will suffice. Instead, public support must be obtained through a concerted education and information program by responsible governmental agencies or interested citizens' groups. In Florida, for example, a common problem united 


\section{COASTAL ENGINEERING}

a number of local groups and agencies into the Florida Shore and Beach Preservation Association. This organization, which received part of its stimulus from the success of similar groups in other states, has been instrumental in specifying by legislative act the responsibility of the Trustees of Internal Improvement Fund for erosion control and beach preservation. In addition it has acquired support for the program of the Coastal Engineering Laboratory, and has the promise of providing an indispensable service in educating the public.

Active participation by both the government - determine by law - and the public - determined by sentiment - is necessary for the consummate success of a coastal program. Discussion thus far has pointed up the fundamental deficiency of each. First, over-refinement of laws encourages undue reliance on the provisions of the law, limiting its application and curbing initiative. Second, without public interes and support, no law, whether infinitely detailed or broadly permissive, can provide a remedy for coastal problems. The conclusion reached is simple, and yet profound: coastal law are necessary for a remedial program, but until such time as these laws become mandatory directives, they must be drawn to enlist the fullest public cooperation, down to the last individual beach property owner.

Although coastal laws have their purposes in common, their application must vary to fit particular circumstances. If the law is not general and flexible, numerous difficultit are likely to be encountered. Procedures and policies shou. evolve through interpretation of the law rather than writtel into it, and local acceptance must be insured through adapt: tions. If coastal conditions become so critical that hazar are created, human life is endangered and the public intere in private property is jeopardized, tre law should provide for positive governmental action. otherwise, the initiativ should be fostered at the lowest practical level.

\section{PROVISIONS OF PRACTICAL COASTAL PROTECTION LAW}

To be practical, coastal protection laws should provid for what may be done, the scope within which and the means which it may be done, and who may do it.. If coastal conditions are critical enough, these provisions should require mandatory execution; otherwise permissive powers should be granted for use at whatever level the initiative is taken. As previously emphasized, the law must not be over-refined, but must authorize a liberal approacn, adaptable to particu situations.

\section{BEACH PRESERVATION LAW}

In considering what the law should provide, the need 


\section{LEGAL ASPECTS IN COASTAL PROTECTION ENGINEERING}

for coastal protection can be logically divided according to source: human or natural. Human activities sucil as mining, dredging, filling and construction are often detrimental to beacnes and coastlines, and may be regulated through a beach preservation law. The law may simply forbid such activities or may prescribe desirable limitations or restrictions. Offshore activities, which may be as harmful as those on the beach itself, should also be controlled. Responsibility for enactment and administration of this law should be in the political entity which legally holds title to coastal areas beyond the line of private ownership.

\section{COASTAL PROTECTION LAW}

Protection of shores and beacnes from natural factors involves measures of greater complexity, and the law enacted for this purpose should provide correspondingly broader authority without attempting to prescribe superfluous procedural details. There are five basic provisions which should be incorporated into the coastal protection law:

(a) a provision creating an agency in the central government, or placing the responsibility for coastal protection in an existing agency of the central government

(b) a provision requiring certain measures to be undertaken to protect life and property, prevent hazards from products of storm and flood, and uphold the general public interest in private as well as public property

(c) a provision authorizing measures to be undertaken at lower levels to prevent and remedy damage and loss of property through natural processes such as erosion

(d) a provision authorizing the establishment of cooperative organizations for the purpose of shore and beach preservation and coastal protection at lower levels

(e) a provision authorizing participation by the central government, through financial and technical assistance, in coastal protection activities at lower levels and establishing formulae for determining the extent of governmental participation

These provisions are more or less comprehensive, and 
It may be desirable to delegate them to one or more lower governmental levels within the central government, dependine largely on tre size of $\tau_{1}$ political entity assuming the responsibility and the polltical subdivision system in lise. A small state with a relatively short coastline might easily assume each of these functions, whereas a large country with a more heterogeneous coastline might prefer to place these functions within local governments. In any case, an unequivocal line of responsibility should be maintained and the advantages of some overlap of duties at each level should be considered.

The coastal protection agency - Whenever a coastal protection law is enacted, there should properly be an agenc of the government to represent the public interest in the discharge of the provisions of the law. This agency may interest itself to some extent directly in coastal protectic and remedial programs, but primarily it serves as supervisol and coordinator of subordinate activities, and as adviser tc the governmental executive. Liberal powers toward the exect tion of a comprehensive coastal protection program should bi vested in tais agency.

Mandatory requirements for protection of life and public property - Many consequences are likelj to result from the action of natural forces on unregulated human development and use of coastal areas. Some of these consequences are confined in their efiects, and cause no immedia public concern. There are others, however, caused or aggra vated by individual or local activity, which have f'ar reaching effects and are of vital concern to the public as a whole. Among these consequences are the loss or jeopardy of human life through actıon of storms and floods on inadequately protected coastal areas, the development of public health hazards, and tile destruction of public property. The coastal protection law should serve to preve or eliminate such conditions beiore they become consequenti requiring manatory adherence to prescribed standards ot" public safety and coastal development.

Authority for individual coastal protection measures Any individual or several coastal property owners should enjoy the right to undertake measures for tile protection of their property from natural forces. To insure an orderly approach to tnis problem, tre coastal protection law shoulc authorıze private activities subject to approval and supervision by the government or the techniques and structures to be used. Since sucn measures frequently entall construc tion on piblic property below tre line of private ownershis usually tile mean or ordinary high water line - the law should authorize sucn invasion for legitimate purposes. 


\section{LEGAL ASPECTS IN COASTAL PROTECTION ENGINEERING}

Local cooperative organizations. - In many cases, coastal protection or beach preservation needs do not involve the entire limits of a particular local government, yet exceed the scope of individual property owners. The desirable recourse is the establishment of a district, covering the entire problem area. This district could take the place of a local government to et'fectuate a cooperative program. The basic coastal protection law should provide blanket authority for creation of beach erosion districts or similar organizations, and provide a framework within which they mignt function.

Governmental participation in coastal protection programs - Some pubito benefit accrues from almost all properly planned and executed coastal protection programs. For thls reason the central government may desire to participate to some extent in protective and remedial programs for private property, as well as conducting programs for entirely public property. The assistance and incentive to be fained locally from governmentai participation is extremely valuable, since coastal technology is not a common science and the planning and construction of coastal projects is costly. Coastal protection laws should make some provision to enable participation by the central government, and snould set forth terms on $W_{12 i} c_{1}$ to base the amount of assistance to local governments, beach erosion districts and possibly individual property owners where the public interest is surficiently sreat.

Provision for beach preservation and coastal protection needs as out linea above, liberally drafted in a law compatible with a particular constitution or charter, will afford a general and comprehensive basis to undertake or foster the actual protective and remedial programs. It would serve little purpose to elaborate on the numeroxs ways bj which these provisions could be represented ir tne liw, or on the even more numerous ways by which the legal provisions could be implemented. These are considerations which must be influenced by the needs and desires of a particular covernment. It will probably be of value, however, to examine selected provisions of existing law to gain the benefit of experience by other governments with perhaps similar coastal problems.

\section{PROVISIONS OF EXISTING COASTAL LAW}

Coastat laws currently in use by various governments of the world have evolved - or are evolving - in a manner responsive to the needs occasioned by conditions in the area. These conditions represent a complex of physical, legal, cultural and related factors which determine differences 


\section{COASTAL ENGINEERING}

in the laws, or whether or not there is a law at all. The result has been a wide range of experience in producing coastal protection laws among various countries, and amons the various states of the United states. Provisions of some of the representative existing coastal laws are summarized below.

DENMARK

Denmark has two different kinds of beach laws:

(a) a beach preservation law, and

(b) a coastal protection law.

The beach preservation law which is now in use was iss in 1906. It provides that when it is necessary for the pro. tection of the coast, all removal of sand, clay, gravel and stones can be forbidden. Exemptions are sometimes made for such purposes as the removal of material for coastal protection work.

Executive power is in the hands of the Ministry of Pub. Works, which, when such a question arises, establishes a "coastal commission" for each county involved. Out of the three members on each commission the chalrman is selected $b$. the Ministry of Public Works (usually a district engineer from the ministry), and the two other members are appointed by the county commissioners, although they do not need to $b$ county, commissioners. The commission works out a proposal and holds a hearing before reaching its decision. The deci sion may be protested, but if the ministry sustains it, the decision is valid for five years. At the end of five years the matter can be re-considered if requested.

Coastal protection law now in use requires the approva of the Ministry of Public Works for any coastal structure built outside the mean high water line. The ministry can refuse to allow constructions which are inadequately desigr and will have a detrimental effect on the adjacent coastal property. If support from government funds is applied for, the legislators act on each individual request through the "financial committee", There are no general rules regardir the financial participation by the government. On the Nort Sea coast a contribution of $100 \%$ may be made where it is considered important for the country as a whole to counter: erosion. The total amount of government funds usually is based on the percentage of public interest in the area to 1 protected. In the "Inner seas", the Baltic and the Sounds. the government usually will contribute one-third, the coun 


\section{LEGAL ASPECTS IN COASTAL PROTECTION ENGINEERING}

one-third, and private interest one-third. If a city is involved, it may take over the whole cost, or share it with private interests. These are divided into two or three classes according to their interest in the matter. Class one has coastal property and pays twice as much per linear meter of protection as class two, which has its property inland from class one. Class three, if any, is inland from class two, and pays half as much as class two. The power is in the hands of a "property commission", similar to the coast commission described above. The chairman is usually a judge and is appointed by the Ministry of Public Works.

An important provision of the coastal protection law prescribes a means by which neighboring property owners may be assessed for a proportional share of the cost when benefits are derived from a project undertaken by another owner. The party initiating the project may request the property commission to determine the extent of the benefits to neighboring property and assign expenses for construction and maintenance accordingly. If the property commission deems it necessary that a coastal protection structure extend beyond the property of the builder to achieve proper results, it may grant such permission, even over the adjoining property owner's objection.

\section{HOLLAND}

Holland has no special coastal laws. Its program functions under a number of laws of more general tenor. The most important of these is the "Waterstaat" act, issued in 1900, which gives general rules for government, dealing with the regulation of the water and the defense against the sea in any situation.

Among the provisions of the Dutch law is that establishIng water-divisions, or "waterschappen", which are in some ways similar to Florida beach erosion prevention districts. These waterschappen are arranged at different levels of authority and jurisdiction, and have the power to pass local legislation regarding defense against the sea. In many cases a lower level waterschappen must yleld to the superior authority of a higher division, but otherwise it is responsible for coastal protection activities within its own province. In emergencies such as that which occurred in 1953, it is possible for most of the divisions to mobilize every ablebodied male between the ages of 10 and 65 for work at dikes and sea defenses.

Waterschappen are governed by a committee elected by the owners of the property within the limits of the division. The number of votes any owner has is dependent upon the size and use of his property. The chairman and members of the 


\section{COASTAL ENGINEERING}

commission responsible for the over-all management of water divisions are appointed by the crown. Final authority over all divisions is vested in the crown. When the situation warrants, the official of the Ministry of Waterstaat may, in the name of the crown, take command of any local situatic

All the beaches and the connecting dunes are part of Holland's defense against the sea, and for this reason are under control of the Ministry of Waterstaat. All land on $t$ seaward side of the high water line is always owned by the state. In most cases the state or division also owns a narrow strip on the shoreward side of the nigh water line, but in a very few cases this strip may be private property.

A waterschap may be established whenever a certain percentage of the property owners in a district requests it: or if the crown deems it necessary. The Waterstaat act states that public or private property may be used for digg: surveying or erecting of certain signs necessary for the design and execution of coastal protection works, provided written notice is sent to owners or users of the property, at least 48 hours in advance. The act also provides that nt coastal defense works in an area under management of a waterschap are to be approved by the county authorities, or the Ministry of Waterstaat. Every county has its own hydraulic engineering division. The waterschappen, the county authorities and the Miristry of Waterstaat are joint. responsible for the management of the coastal protection works.

Activities of possible detriment to the foreshore, dun or coastal waters are tightly regulated. For example, it i forbidden to dredge on the foreshore within a distance of 1500 feet from the toe of the dunes or the existing coastal protection works. Destruction of vegetation in these areas is especially prohibited.

If coastal protection structures built under the autho ity of a waterschap prove to be beneficial outside the division's limits, a contribution to the cost of these work may be paid by the county authorities and the government. The ratio of these contributions depends on the circumstanc but in case of emergency the state may pay the whole cost.

\section{UNITED STATES}

Provisions of United States law concerning beach pres $\epsilon$ vation and coastal protection are contained in a number of acts dating back to the important Rivers and Harbors Act of 1930. The nost signiticant of the separately enacted laws are described here. 


\section{LEGAL ASPECTS IN COASTAL PROTECTION ENGINEERING}

Public Law 520, Seventy-lirst Congress, 1930 - This law created a seven man beach erosion board under the chief of Engine ers, U. S. Army, to Iurnish technical assistance and otherwise supervise and participate in investigations and studies made in cooperation with the states to determine beach erosion needs and remedies. The corps of dingineers was assigned the primary responsibility for conducting the cooperative studies.

Public Law 166, Seventy-ninti Congress, 194y - Additional responsibility was placed on the Corps of Englneers, through the Beach Erosion Board, which was directed to conduct general investigations at federal expense to protect, restore and develop the beaches. The responsibility of the Board under P. I. 520 was increased to include an opinion on (a) the advisability of adopting the project, (b) what public interest, if any, is involved in the proposed improvement, and (c) what share of the expense, if any, should be borne by the United States.

Public Law 727, Seventy-ninth Congress, 1946 - For the purpose of "preventing damage to public property and promoting. and encouraging the healthful recreation of the people", this law authorized ftederal financial assistance for the construction, but not the maintenance, of coastal protection works. The project must be for public property, and must be recommended by the Beach Erosion Board and specifically authorized by Congress. Federal funds are limited to a maximum of onethird of the total cost of the project.

Public Law 826, Eighty-fourth Congreas, 1956 - Important amendments to P. L. 727 were made by this law. Shores of territories and possessions were specifically mentioned for the first time. Also, provision was made to interpret "artificial nourishment" as a limited form of construction previously provided for. Probably most important is the broadening of the provisions of the act to include all shores, whether public or private, where public interests are involved.

\section{INDIVIDUAL STATES}

of the forty-eight united states, twenty-two have a marine shoreline and six others have a shoreline on the fresh water Great Lakes. A vast difference is manifested among the coastal and beach laws triat have been developed throughout the country. Georgia, Loulsiana, Maine, New Hampshire and oregon have no beach laws to speak of, while some states operate under highly effective statutory provisions.

Florida - The basic statute under which florida has authorized $a$ beach preservation and coastal protection program is Section 253.03, Florida statutes, described in the initial 


\section{COASTAL ENGINEERING}

part of tuis paper. The Trustees of the Internal Improvement Fune were so empowered as early as 1931, but little has been accomplished under that authority.

In 1941, a law was enacted which became chapter 158, Florida statutes, authorizing the establishment of beach erosion prevention districts. This law provides that any election precinct in the state may by majority vote organize as an erosion prevention district, with all the powers and functions necessary for undertaking a program of 1 is own or cooperating with the federal and state gover ments. Only a limited number of such districts has been created, but these are in some of the areas of most critic need.

It has always been the responsiblilty of the Trustee of the Internal Improvement Fund to administer sovereign tidal lands and regulate their alteration and development Inconsistent lesislation in past years has produced such legal confusion that the Trustees' task has been extremel: difficult. The 1957 Legislature enacted Chapter 57-362, Laws of Florida, vesting an unequivocal authority in the Trustees and repealing several conflicting statutory provisions. Of greatest significance in this law is the establishment of a procedure by which local governments under the over-all supervision of the Trustees shall fix bulkhead lines in tidal waters to control dredging, fili1 and similar alterations. Broad application of Chapter 57-362 is currently being made.

Another important act passed by the 1957 Florida Leg1slature, Chapter 57-791, designates the Trustees of the Internal Improvement Fund as the erosion agency of th state, and authorizes the expenditure of surplus funds fo assistance to localities in combating beach erosion. The Trustees' responsibility in the beach preservation fleld is further confirmed, and a department of beach erosion may be created as a part of the Trustees' staff if it proves desirable.

Massachusetts - In Massachusetts, act1vities in shc protection, river and harbor development and stream imprc ment all are authorized by Chapter 91 of the statutes. Section 11 of this law, which pertains more specifically to beach erosion and harbor and channel protection, provj the Department of Public Works with broad authority to undertake such activities for improvement, development, maintenance and protection as 1 t deems reasonable and proper. It has been the policy of the state to require a fifty per cent contribution from local sources toward the cost of beach protection works. A twenty-five per cent local contribution is required for dredging project: if the seneral public interest is served. Local partici] 


\section{LEGAL ASPECTS IN COASTAL PROTECTION ENGINEERING}

must petition the Department of Public Works for assistance and hold a public hearing on the proposed cooperative project.

New York - Erosion prevention and beach protection works in New York State are carried out under the Superintendent of Public Works by authority contained in Chapter 535, Laws of New York. The initiative rests with local or municlpal sovernments, who must enter into an agreement with the state to contribute fifty per cent of the total project cost. Necessary lands or easements are provided by local interests, and plans for the project are drawn by the state, subject to local approval. The state may contract actual construction work or may undertake all or part of it with its own iorces. After completion, the municipality assumes all responsibility for maintenance and repair. Provision is made to utilize assistance from the federal government in any project, but the local obligation remains at fifty per cent of the total cost. Municipalities are authorized to levy a general tax on all taxable real property therein or a special assessment on real property actually benefited by the project.

Ohio - The state of Ohio, which has no marine coastline, has a very detailed shore protection law, pertaining primarily to the shores of Lake Erie. Chapter 1507, Oh1o statutes, vests the responsibility in the Division of Shore Erosion, with authority to cooperate with the federal government and to call upon other state agencies and departments for needed assistance. The Division regulates all activity, either for shore improvement and protection or for mining and removing materials from the beach or lake bottom, through the issuance of permits. The state may enter into agreements with local governments for undertaking: shore protection projects. If the property to be protected is wholly public, the state assumes two-thirds of the project cost and local interests one-third; if private property is to be protected, the ratio is reversed, with the state paying only one-third. In emergencies, the state may act without an agreement for local contribution, and regardless of the ownership of the property involved. The maintenance of completed works also is shared by state and local interests. Responsibility for the preparation and continued modification of a comprehensive plan for erosion prevention is placed in the Division of Shore Erosion.

Michigan - Neither does Michigan have a marine coastline, but its fresh water shore line on the Great Lakes Superior, Michigan, Huron and Erie is extensive. The state itself, however, has not been particularly active in shore protection programs. In 1952, two measures were enacted 


\section{COASTAL ENGINEERING}

by the Legislature to authorize initiative at the local township or municipal level. Act No. 44, 1952, authorizes any political subdivision of the state to make expenditures from its general or contingent funds for beach protection work, Act No. 278, 1952, further authorizes local governments to enter into agreements and cooperate with tile f'edera: government in any of its natural resource or conservation programs, including beach erosion control.

California - Control over beach erosion in California formerly was vested in the state Park Commission, under the immediate supervision of a beach erosion control engineer. In 1953, the office of the engineer was abolished and the powers and duties relating to control of beach erosion were transferred to the Department of Public Works. In 1956, these functions were transferred to the newly created Department of Water Resources.

Sections 330-334 of the state water code outline the existing authority pertaining to the control of beach erosion. Provision is made for the conduction of studies independently or in conjunction with other local, state or federal agencies. Within certain financial limitations, the Department of Water Resources may plan and construct whatever works the studies indicate to be necessary. Specific authority is provided for cooperation with the federal government or other agencles in constructing beach protection works. 